\title{
PERSEPSI PETERNAK SAPI BALI TERHADAP UREA MOLLASES BLOK DI KABUPATEN MAROS, SULAWESI SELATAN
}

\author{
The Perception of Bali Cattle Farmers Toward Urea Mollases Block in Maros Regency, \\ South Sulawesi Province
}

\author{
Veronica Sri Lestari', Djoni Prawira Rahardja', Ikrar Mohammad Saleh ${ }^{1}$, Aslina Asnawi ${ }^{1}$ \\ dan Kusumandari Indah Prahesti ${ }^{1}$ \\ ${ }^{1}$ Fakultas Peternakan Universitas Hasanuddin Makassar \\ Email: veronicasrilestari@yahoo.com
}

\begin{abstract}
ABSTRAK
Urea Molasses Blok (UMB) merupakan pakan tambahan untuk ternak ruminansia. Tujuan dari penelitian ini adalah untuk mengetahui persepsi peternak sapi Bali terhadap penggunaan UMB. Penelitian ini dilaksanakan di Kabupaten Maros, Provinsi Sulawesi Selatan. Jumlah sampel dalam penelitian sebanyak 30 peternak yang ditentukan secara purposive. Data diperoleh melalui wawancara menggunakan kuesioner dengan jumlah pertanyaan sebanyak 9 buah. Seluruh data penelitian ini diukur melalui item pertanyaan dengan 3 poin Skala Likert yaitu dari Tidak Setuju (TS) skor 1, Setuju (S) skor 2, dan sampai Sangat Setuju (SS) skor 3. Variabel yang diamati dalam penelitian ini adalah karakteristik peternak meliputi umur, gender, tingkat pendidikan, pengalaman beternak dan jumlah ternak sapi yang dimiliki dan persepsi peternak terhadap inovasi UMB yang meliputi adalah pernyataan responden tentang inovasi yang menjalankan usahanya yang meliputi keuntungan relatif (relative advantage), tingkat kesesuaian (compatibility), tingkat kerumitan (complexity), tingkat kemudahan untuk dicoba (trialability), dan mudah diamati atau dirasakan (observability). Data yang digunakan dalam penelitian ini adalah data primer dan data sekunder. Data diolah menggunakan perangkat lunak SPSS versi 23,0, dandianalisis secara statistik deskriptif. Hasil penelitian menunjukkan bahwa persepsi peternak sapi Bali di Kabupaten Maros, Propinsi Sulawesi Selatan berada pada kategori sangat setuju terhadap penggunaan UMB.
\end{abstract}

Kata kunci: UMB, Sapi Bali, Persepsi, Peternak

\section{ABSTRACT}

Urea Molasses Block (UMB) was used as additional feed for ruminants. The purpose of this study was to know the perceptions of Bali cattle farmers toward UMB. The research was conducted in Maros Regency, South Sulawesi Province. A total of 30 farmers breeders were determined purposively. Data were obtained through interviews by using a questionnaire. There were consist of 9 questions. All assessments in this study discuss questions posed with 3 points Likert Scale ranging from Disagree (TS) score 1, Agree (S) score 2, and Strongly Agree (SS) score 3. Variables in this study were the characteristics of farmers consisted of age sex, level of education, experience raising Bali cattle, and the number of Bali cattle. Farmers' perception of UMB was the respondent's agreement on innovations for related efforts: relative advantage, compatibility, complexity, trialability, and observability. The data used in this study were primary data and secondary data. Data were processed using SPSS software version 23.0. Data were analyzed statistically descriptive. The results showed that the perception of Bali cattle farmers breeders toward UMB in Maros Regency, South Sulawesi Province was categorized as strongly agree.

Keywords: UMB, Bali Cattle, Perception, Farmers 


\section{PENDAHULUAN}

Sapi Bali merupakan salah satu aset nasional yang cukup potensial untuk dikembangkan. Penyebaran sapi Bali telah meluas hampir ke seluruh wilayah Indonesia, hal ini disebabkan karena karena breed ini lebih diminati oleh para petani peternak disebabkan beberapa keunggulan yang dimilikinya, antara lain tingkat kesuburan yang tinggi, sebagai sapi pekerja yang baik dan efisien serta dapat memanfaatkan hijauan yang kurang bergizi dimana bangsa lain tidak dapat, persentase karkas tinggi, daya adaptasi yang tinggi terhadap lingkungan dan persentase beranak dapat mencapai 80\% (Ngadiyono, 1997).

Biaya pakan ternak adalah $60 \%$ dari biaya produksi. Supaya peternak mendapatkan keuntungan, maka biaya produksi yang tinggi harus menghasilkan produksi yang tinggi. Oleh karena itu untuk meningkatkan produktivitas ternak sapi diperlukan inovasi teknologi. Salah satu teknologi yang digunakan dalam perbaikan mutu pakan ternak adalah Urea Molasses Blok (UMB). Suharyono et al. (2014) menyatakan bahwa UMB memiliki dampak positif pada pendapatan petani. Ditambahkan oleh Rawenda \& Sabir (2016) bahwa UMB adalah suplemen pakan sebagai sumber protein, energi dan mineral yang dibutuhkan untuk ruminansia, padat dan kaya nutrisi.

Roger (2003) menyatakan bahwa ada lima karakteristik inovasi, yaitu: keuntungan relatif, kompatibilitas, kompleksitas, trialabilitas dan kemampuan untuk diamati (observabilitas). 1) Keuntungan Relatif: Inovasi akan diadopsi lebih cepat jika manfaat relatifnya lebih besar. 2) Kompatibilitas: Kesesuaian inovasi dengan nilai-nilai sosial dan budaya dari suatu daerah dan norma akan mempengaruhi proses adopsi inovasi. Misalnya, jika suatu inovasi atau ide-ide baru tidak sesuai dengan nilai dan norma, sehingga inovasi tidak dapat diadopsi. 3) Kompleksitas: adalah sejauh mana suatu inovasi dianggap relatif sulit dipahami dan digunakan, berbeda dengan atribut lainnya, kompleksitas berkorelasi negatif dengan tingkat adopsi. 4) Trialibilitas: Kemampuan untuk diuji adalah di mana suatu inovasi dapat diuji dengan benar. 5) Observabilitas: Kemampuan untuk mengamati adalah sejauh mana hasil suatu inovasi dapat dilihat oleh orang lain. Semakin mudah seseorang melihat hasil suatu inovasi, semakin besar kemungkinan orang atau kelompok orang tersebut mengadopsi.

Masalah yang dihadapi di Indonesia adalah produksi daging dalam negeri tidak dapat memenuhi permintaan domestik, sehingga diperlukan impor ternak sapi dan daging beku dari negara tetangga seperti Australia dan Selandia Baru. Menurut Arifin (2020), kebutuhan sapi di Indonesia pada tahun 2018 adalah sebanyak 773.720 ton. Populasi sapi lokal 17 juta ekor, impor sapi hidup 400 ribu ekor dan impor daging sapi 160.000 ton.

Kabupaten Maros menduduki urutan kelima dalam populasi ternak sapi potong di Sulawesi Selatan. Pada tahun 2015 jumlahnya ada 76.381 ekor. Selama ini peternak memelihara secara semi intensif yaitu pada siang hari, ternak sapi dilepas, pada malam hari dikandangkan dengan kandang seadanya, terkadang dibawah kolong rumah atau disamping rumah, pakan mengandalkan hijauan dan dedak, skala pemilikan kecil dan minim teknologi. Peternak memelihara sapi sebagai tabungan dan sebagai usaha sampingan. Peternak dapat menjual ternak sapinya kapan saja mereka membutuhkan uang. Usaha pokok mereka adalah bertani dan berkebun.

Berdasarkan hal tersebut maka dilakukan introduksi teknologi pengolahan pakan dalam bentuk UMB. Tujuan penelitian ini adalah mengetahui persepsi peternak sapi Bali terhadap UMB.

\section{METODE PENELITIAN}

Penelitian ini dilakukan di Kabupaten Maros tepatnya di Kecamatan Tanralili. Jumlah sampel 30 peternak sapi Bali yang ditentukan secara purposive. Data yang dikumpulkan terdiri dari data 
primer dan data sekunder. Data primer diperoleh melalui wawancara menggunakan kuesioner, sedangkan data sekunder diperoleh dari data BPS dan Dinas Peternakan setempat. Untuk mengetahui persepsi peternak sapi Bali, digunakan variabel yang diadopsi dari Roger terdiri dari relative advantage, compatability, observability, complexity dan trialability. Skala Likert digunakan untuk mengetahui respon peternak terhadap UMB dengan skala terendah 1 tidak setuju, 2 setuju dan sangat setuju dengan skor 3. Data diolah menggunakan perangkat lunak SPSS versi 23 dan dianalisis secara deskriptif kuantitatif.

Untuk mengukur variabel-variabel relative advantage, complexity, compatability, trialability dan observability, digunakan rumus sebagai berikut :

(1) Nilai maksimum $=3 \times 30=90$

(2) Nilai minimum $=1 \times 30=30$

Jarak kelas $\quad=90-30=20$

3

Nilai Persepsi dapat diketegorikan sebagai berikut:

Sangat setuju $=70-90$

Setuju $\quad=50-69$

Tidak setuju $=30-49$

Total Persepsi dapat dihitung dengan rumus:

Nilai maksimum : $3 \times 30 \times 5=450$

Nilai minimum : $1 \times 30 \times 5=150$

Rentang kelas $=450-150=100$

3

Hasilnya dapat dikategorikan sebagai berikut:

Sangat setuju $=350-450$;

Setuju $=250-349$;

Tidak setuju $\quad=150-249$.

\section{HASIL DAN PEMBAHASAN}

\section{Karakteristik responden}

Berdasarkan Tabel 1 dapat dilihat bahwa responden berada pada usia produktif dengan umur rata-rata 35,27 tahun. Untuk memelihara sapi Bali diperlukan tenaga yang kuat, oleh karena itu usia responden yang termasuk usia produktif sangat mendukung peternakannya.

Tabel 1. Karakteristik Peternak Sapi Bali di Kabupaten Maros, Sulawesi Selatan

\begin{tabular}{|c|c|c|c|c|c|}
\hline No & Keterangan & Minimum & Maksimum & $\begin{array}{l}\text { Rata } \\
\text { rata }\end{array}$ & $\begin{array}{l}\text { Standar } \\
\text { deviasi }\end{array}$ \\
\hline 1 & Umur (tahun) & 14,00 & 70,00 & 35,27 & 16,18 \\
\hline 2 & $\begin{array}{l}\text { Jenis kelamin } \\
\begin{aligned} \text { a. } & \text { Laki-laki }(86,67 \%) \\
\text { b. } & \text { Perempuan }(13,33 \%)\end{aligned}\end{array}$ & & & & \\
\hline 3 & Pendidikan (tahun) & 6,00 & 16,00 & 9,35 & 2,89 \\
\hline 4 & $\begin{array}{l}\text { Pengalaman beternak sapi } \\
\text { (tahun) }\end{array}$ & 1,00 & 30,00 & 7,70 & 8,58 \\
\hline 5 & Jumlah ternak (ekor) & 1,00 & 10,00 & 3,53 & 2,46 \\
\hline
\end{tabular}

Ditinjau dari jenis kelamin, dapat dilihat bahwa mayoritas responden lebih banyak laki-laki dibandingkan perempuan yaitu $86,67 \%$ berbanding $13,33 \%$. Persentase laki-laki yang tinggi 
merupakan sumber daya manusia yang dapat dimanfaatkan seoptimal mungkin, karena dipeternakan sapi diperlukan tenaga untuk mencari rumput, membersihkan kandang, memberi pakan, menjual ternak dan menjaga ternak sapi dikebun. Persentase perempuan yang beternak sapi sedikit karena mereka sudah disibukkan dengan kegiatan domestik rumah tangga seperti memasak, mencuci, merawat anak dan membersihkan rumah.

Rata-rata responden pernah mengenyam pendidikan selama 9,35 tahun, artinya mereka lulus dari Sekolah Menengah Pertama. Semakin tinggi pendidikan maka semakin tinggi tingkat adopsi terhadap suatu inovasi. Dilihat dari pengalaman beternak, rata-rata adalah 7,70 tahun. Semakin lama pengalaman beternak, maka semakin bagus dalam mengambil keputusan apabila ada masalah dikandangnya. Jumlah pemilikan ternak rata-rata adalah 3,53 ekor, hal ini menunjukkan peternak berada pada kategori skala kecil. Peternak sapi Bali di Kabupaten Maros memelihara sapi bukan sebagai usaha pokok, sehingga tidak ada motivasi untuk menambah jumlah ternak sapinya.

\section{Persepsi peternak sapi Bali terhadap Urea Mollases Blok (UMB)}

Berdasarkan Tabel 2 dapat dilihat bahwa persepsi peternak sapi Bali terhadap UMB termasuk kategori sangat setuju dengan nilai total 368,00. Hal ini sependapat dengan penelitian yang dilakukan oleh Lestari et al. (2016) di Kabupaten Gowa dan Lestari dkk. (2018) di kabupaten Barru, Sulawesi Selatan. Penelitian ini berbeda dengan pendapat Lestari dkk. (2019) yang mengatakan bahwa persepsi peternak sapi potong di kabupaten Soppeng terhadap UMB sebagai pakan tambahan termasuk kategori setuju.

Tabel 2. Persepsi Peternak Sapi Bali Terhadap UMB

\begin{tabular}{lclcc}
\hline \multicolumn{1}{c}{ Variabel } & & Kategori & Bobot & Persentase \\
\hline Keuntungan & relative $\quad$ (Relative & a. Sangat setuju & 75,00 & 93,75 \\
advantage) & b. Setuju & 4,00 & 5,00 \\
& c. Tidak setuju & 1,00 & 1,25 \\
Kesesuaian adat budaya lingkungan & a. Sangat setuju & 51,00 & 70,83 \\
(Compatability) & b. Setuju & 20,00 & 27,78 \\
& c. Tidak setuju & 1,00 & 1,39 \\
Kerumitan (Complexity) & a. Sangat setuju & 45,00 & 70,31 \\
& b. Setuju & 8,00 & 12,50 \\
Dapat diamati (Observability) & c. Tidak setuju & 11,00 & 17,19 \\
& a. Sangat setuju & 57,00 & 75,00 \\
& b. Setuju & 16,00 & 21,05 \\
Dapat diuji coba (Trialability) & c. Tidak setuju & 3,00 & 3,95 \\
& a. Sangat setuju & 60,00 & 78,95 \\
& b. Setuju & 12,00 & 15,79 \\
& c. Tidak setuju & 4,00 & 5,26 \\
\hline
\end{tabular}

\section{KESIMPULAN}

Berdasarkan penelitian ini dapat disimpulkan bahwa persepsi peternak sapi Bali terhadap Urea Mollases Blok di kabupaten Maros, Sulawesi Selatan berada pada kategori sangat setuju.

\section{UCAPAN TERIMA KASIH}

Ucapan terima kasih disampaikan kepada Universitas Hasanuddin atas dukungan moril dan materiil dalam kegiatan ini melalui dana BOPTN 2020. 


\section{DAFTAR PUSTAKA}

Arifin, M. (2020). Sistem budaya ternak ruminansia untuk menghasilkan daging berkualitas. Webinar Indonesia Livestock Club. Edisi 7. Tema: Hulu-Hilir dalam Menghasilkan Daging Berkualitas. 1 Agustus 2020.

Lestari, V. S., Rahardja, D. P., Rasyid, T., Asnawi, A., Saleh, I. M., \& Rasyid, I. (2016). Beef cattle farmers perception toward urea mineral molasses block. World Academy of Science, Engineering and Technology International Journal of Agricultural and Biosystems Engineering Vol:10, No:10.

Lestari, V. S., Rahardja. D. P., \& Sirajuddin, S. N. (2018). Persepsi peternak sapi potong terhadap Urea Mollases Blok. Prosiding Seminar Nasional PERSEPSI III (Perhimpunan Ilmuwan Sosial Ekonomi Peternakan), 6-7 September 2018, Manado: PERSEPSI.

Lestari, V. S., Rahardja. D. P., Saleh, I. M. \& Sirajuddin, S. N. (2019). Persepsi peternak terhadap Urea Molasses Blok sebagai pakan tambahan. Prosiding Seminar Nasional PERSEPSI IV (Perhimpunan Ilmuwan Sosial Ekonomi Peternakan), 21-22 Agustus 2019, Makassar: PERSEPSI.

Ngadiyono, N. (1997). Kinerja dan prospek sapi Bali di Indonesia. Seminar - IAEUP Enviromental Pollution and Natural Product and Bali Cattle in Regional Agriculture, Bali.

Rawendra, R. \& Sabir. (2016). Gerakan Pemberdayaan Petani Terpadu. Balai Besar Pelatihan Peternakan Batu, Batu, Malang: Media Nusa Creative.

Rogers, E, M. (2003). Diffusions of Innovations, Fifth Edition. London: Simon \& Schuster Publisher.

Suharyono., Sutanto, H., Purwanti, Y., Martanti., Agus, A., \& Utomo, R. (2014). The effect of urea molasses multi-nutrient and medicated block for beef cattle, beef and dairy cow. Atom Indonesia, 40(2), 77. 